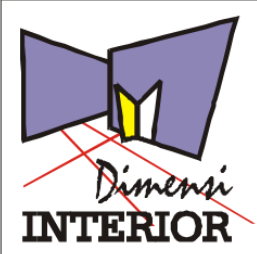

http://dimensiinterior.petra.ac.id

\title{
Perancangan Produk Kriya Interior Berbahan Limbah Kayu Pabrik Gitar Di Ujung Berung Bandung
}

\author{
Agus Dody Purnomo \\ Program Studi Desain Interior - STDI, Bandung \\ Email: adp_enggar@yahoo.co.id
}

\begin{abstract}
ABSTRAK
Salah satu permasalahan di kota Bandung yakni limbah industri. Sebagai contoh limbah kayu dari pabrik gitar Genta. Selama ini penanganan limbah tersebut dengan membuang dan membakar. Hal ini tentu akan berdampak pada permasalahan lingkungan. Sementara limbah tersebut merupakan kayu yang sudah diolah dan jenis kayu yang bagus. Penelitian ini menjawab permasalahan limbah yang tidak bernilai diolah menjadi produk yang bernilai estetis dan ekonomis. Metode yang dilaksanakan melalui metode perancangan produk. Mulai dari survei, analisis, proses desain, workshop, dan evaluasi. Kreatifitas dan desain dibutuhkan dalam mengolah limbah kayu. Luaran yang dihasilkan dalam penelitian ini adalah prototype produk kriya interior yang siap diproduksi. Penelitian ini diharapkan mampu menjadi langkah nyata untuk meminimalisir limbah kayu pabrik gitar.
\end{abstract}

Kata Kunci: limbah kayu, produk kriya, desain.

\section{ABSTRACT}

One of the permits in Bandung city is industrial waste. For example wasted wood from Genta guitar factory. So far they handling the wasted by throwed and burned, certainly will have an environmental problems, the wasted is processed wood and good wood. This research addresses the problem of worthless waste, processed into products that has aesthetic and economic value. Design that use is through product design methods. Starting from surveys, analysis, design processes, workshops, and evaluations. Creativity and design needed in wood waste processing. Output produced in this research is prototype interior craft products that can be produced. This research is expected to be a real step to minimize the waste of the guitar factory.

Keywords: wood waste, craft product, design.

\section{PENDAHULUAN}

Salah satu permasalahan yang dihadapi di kota Bandung bahkan mungkin di kota-kota lain juga adalah bertambahnya limbah yang dihasilkan oleh industri. Industri selain menghasilkan produk utama juga akan menghasilkan limbah industri. Hal ini merupakan kelemahan industri dimana belum dapat memanfaatkan limbah tersebut. Umumnya yang sering dilakukan hanya membuang atau membakar limbah tersebut. Begitupula yang terjadi pada salah satu industri yang berada di kota Bandung yakni pabrik gitar GENTA.

Pabrik gitar GENTA berdiri sejak tahun 1959 berlokasi di Bandung dan hingga saat ini masih memproduksi berbagai bentuk gitar akustik maupun listrik. Produknya sudah menembus hingga pasar luar negeri. Dan beberapa musisi terkenal baik dari dalam maupun luar negeri juga sudah mengenal serta memakai gitar buatan Bandung ini. Walaupun buatan lokal akan tetapi produk gitar ini tetap memperhatikan kualitasnya. Hal ini dibuktikan dengan pemakaian material kayu yang sangat berkualitas seperti kayu Mahoni dan Rose wood (Sonokeling).

Dalam setiap kali proses produksi gitar selalu menyisakan limbah kayu. Limbah kayu sisa pembuatan gitar berupa potongan-potongan kayu dan papan. Hingga saat ini limbah tersebut hanya dibuang dan dibakar, secara praktis limbah kayu belum dimanfaatkan menjadi produk daur ulang. Sementara isu lingkungan hidup terus didengungkan khususnya berkaitan dengan program untuk mengurangi limbah yang dihasilkan dari industri. Untuk itu perlu langkah nyata sebagai solusi atas permasalahan itu.

Program Studi Desain Interior Sekolah Tinggi Desain Indonesia (STDI), saat ini memiliki kurikulum yang berkaitan dengan studi produk desain interior. Nama mata kuliahnya yakni Desain Produk Interior. Studi ini memungkinkan mahasiswa desain interior untuk mengembangkan produk interior melalui berbagai material, seperti limbah kayu. Oleh karena itu, peneliti beranggapan bahwa studi desain interior dapat menjadi 
solusi ringkas bagi persoalan daur ulang limbah khususnya pada limbah kayu pabrik Genta. Selain itu melalui keilmuwan desain mampu menambahkan nilai lebih pada limbah kayu yang dijadikan objek penelitian.

\section{METODOLOGI}

Penelitian ini menggunakan metode perancangan desain yang meliputi tahapan sebagai berikut: diawali dengan survei lapangan yang bertempat di pabrik gitar PT. GENTA TRIKARYA, Ujung Berung, Bandung. Survei dimaksudkan untuk mendapatkan informasi lengkap tentang limbah kayu mulai dari jenis, ukuran, bentuk, dan karakteristik kayu. Dari survei awal diperoleh beberapa sampel limbah kayu untuk dipakai sebagai data awal.

Teknik pengumpulan data juga dilakukan melalui studi literatur / tinjauan pustaka pada beberapa artikel jurnal ilmiah yang berkaitan dengan kajian limbah kayu untuk dikembangkan menjadi produk desain. Upaya lain yang dilakukan antaralain: browsing internet, koran, majalah, dan sebagainya. Data yang sudah didapat kemudian dianalisis dan dikelompokan berdasarkan jenis kayu dan ukurannya. Umumnya limbah kayu berupa potonganpotongan kayu yang sudah mengalami proses penyerutan sehingga terlihat tekstur kayunya. Selain itu kayu-kayu tersebut juga sudah diproses menggunakan peralatan vacuum dryer guna mengurangi kadar airnya.

Langkah berikutnya yakni brainstorming dengan partisipan. Partisipan adalah para mahasiswa yang menempuh mata kuliah Produk Desain Interior II. Hal ini sangat memudahkan dalam proses pencarian dan eksplorasi ide desain. Eksplorasi ide dengan pembuatan sketsa awal produk secara manual. Sebelumnya mahasiswa diberi wawasan tentang limbah kayu berikut produk desain yang memungkinkan untuk dibuat. Konsep desain diarahkan kepada produk kriya interior yakni produk sebagai unsur pendukung dalam suatu interior, misalnya: lampu meja, perlengkapan meja makan, dan sebagainya. Produk yang fungsional sekaligus estetis dalam tampilan visual dengan tetap mempertahankan karakter material kayu.

Kegiatan workshop dilakukan di studio STDI. Masingmasing mahasiswa membuat alternatif desain. Prototype berupa sketsa produk kriya interior baik secara manual maupun digital. Gambar sketsa desain dilengkapi dengan gambar teknik/gambar kerja baik notasi ukuran dan finishing produknya. Sedangkan untuk workshop produksi terkendala karena tidak adanya peralatan bengkel kerja. Dari beberapa desain awal dipilih dua alternatif untuk dikembangkan.

Tahap terakhir yakni evaluasi dan penyusunan laporan penelitian. Evaluasi berkaitan dengan proses perancangan, sarana prasarana yang tersedia, dan hasil kegiatan. Kegiatan ini juga merupakan langkah awal perkuliahan Produk Desain Interior II yang dikaitkan dengan kegiatan penelitian. Penelitian dengan mengangkat persoalan nyata yang ada di masyarakat tentang penanganan limbah kayu. Hasil evaluasi merekomendasikan agar kegiatan ini terus dikembangkan ke tahap berikutnya untuk memproduksi prototype-nya. Skema metode perancangan seperti di bawah ini:

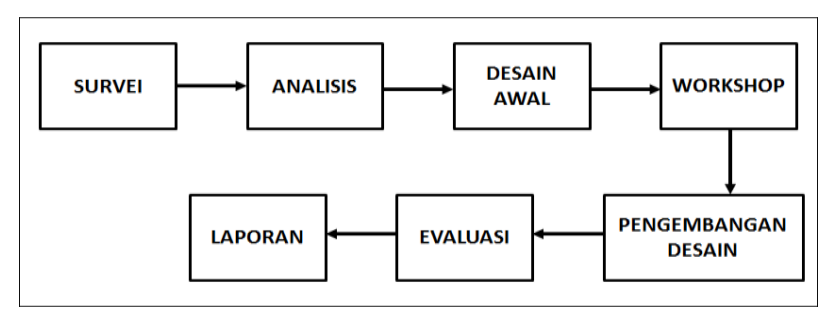

Gambar 1. Skema Metode Perancangan

\section{KAJIAN TEORITIS}

\section{Desain Interior dan isu lingkungan}

Saat ini pemanasan global tidak lagi menjadi sebuah wacana namun sudah benar-benar dirasakan di seluruh dunia. Isu lingkungan selalu mewarnai dalam setiap pembahasan pada semua bidang termasuk didalamnya adalah bidang profesi desain. Salah satu faktor penyebab terjadinya pemanasan global adalah bertambahnya jumlah limbah yang dihasilkan oleh industri.

Dalam perkembangan bidang desain, 'isu-isu' tersebut menjadi perhatian besar sehingga memunculkan istilah baru dalam kajian desain antaralain: Green Design, Eco Design, Desain Ramah Lingkungan, Desain Daur Ulang, dan lain sebagainya, yang intinya desain diharapkan mampu menjadi solusi untuk menjawab permasalahan tersebut.

Hal ini juga menjadi pertimbangan bagi desainer dalam berkarya. Sebagai contoh dalam penilaian kompetensi profesi desainer interior, kepedulian terhadap isu lingkungan menjadi poin penilaian. Pada unit kompetensi etika profesi, seorang desainer dituntut untuk melaksanakan pelestarian lingkungan yang berkelanjutan, antaralain: menghormati dan menjaga kelestarian budaya, memperhatikan dampak penggunaan produk pada lingkungan, memperhatikan kesehatan pengguna ruang, dan menyadari keterbatasan sumber alam yang digunakan (Pedoman Sertifikasi Keahlian Desainer Interior, 2005: hal. 12).

Dalam Musyawarah Nasional (Munas) XI Himpunan Desainer Interior Indonesia (HDII) tahun 2008, Solichin Gunawan selaku Dewan Kode Etik HDII, mengingatkan kembali dalam kata sambutannya, bahwa memasuki abad 21 isu lingkungan menjadi sangat penting akibat eksploitasi lingkungan secara habis-habisan. Maka dibutuhkan kepekaan para desainer interior dalam menjalankan pelayanan jasa profesinya yang dilandasi oleh komitmen dan etika profesionalnya untuk bertanggung jawab bagi kehidupan manusia dan budaya jamannya dengan menghasilkan karya-karya desain yang bermanfaat bagi manusia dan lingkungan hidupnya (Buku Sebelas Munas HDII, 2008 : hal. viii).

Berkaitan dengan kajian penelitian ini diharapkan mampu menjawab permasalahan lingkungan dengan cara 
mengurangi atau memanfaatkan limbah industri untuk memenuhi kebutuhan desain interior di masyarakat.

\section{Produk Kriya Interior Berbahan Kayu}

Desain interior adalah karya seni yang mengungkapkan dengan jelas dan tepat tata kehidupan manusia dari suatu masa melalui media ruang. Ruang yang dibatasi oleh adanya lantai, dinding (partisi), dan langit-langit sebagai pembentuk ruangan (Suptandar, 1999: hal.11). Dalam kehidupan masyarakat modern, tuntutan kebutuhan akan lingkungan yang mendukung aktifitasnya cukup tinggi dimana hampir seluruh aktifitas dilakukan di dalam ruangan. Untuk itu desain interior tidak hanya dituntut untuk memenuhi secara fungsional saja namun juga dibuat sedemikian rupa sehingga kebutuhan fisik dan spiritual penghuninya terpenuhi.

Selain adanya unsur pembentuk ruangan (lantai, dinding, dan langit-langit) unsur pendukung dalam desain interior juga diperlukan, misalnya unsur-unsur pengisi ruangan yakni: furniture dan elemen estetis lainnya. Produk kriya interior dapat dimanfaatkan sebagai elemen estetis. Untuk itu dirancang tidak hanya sebagai pajangan ruangan tetapi juga fungsional.

Hingga saat ini produk kriya interior berbahan kayu masih diminati masyarakat baik dari dalam maupun luar negeri. Dimana material kayu memiliki daya tarik dan keunikan teksturnya. Bahkan material kayu dari Indonesia sangat beragam. Menurut Balai Penelitian Hasil Hutan, di Indonesia terdapat sekitar 4000 jenis kayu. Perkiraan ini didasarkan kepada material herbarium yang sudah dikumpulkan dari berbagai wilayah hutan di Indonesia yang jumlahnya mendekati 4000 jenis pohon dengan diameter $40 \mathrm{~cm}$ ke atas (Martawijaya, 2005:1). Ini menunjukan bagaimana kekayaan dan keanekaragaman material kayu yang ada di Indonesia.

Mengingat pangsa pasar produk kriya berbahan kayu masih tinggi maka perlu kreatifitas dan inovasi dalam mengolah kayu limbah industri.

\section{HASIL DAN PEMBAHASAN}

Dari kegiatan survei lapangan bertempat di pabrik gitar Genta mendapatkan data tentang bahan baku kayu yang dipakai. Kayu yang dipakai sebagai bahan utama pembuatan gitar antaralain:

1. Kayu Rose wood / Sonokeling atau nama botaninya Dalbergia latifolia Roxb, famili Papilionaceae. Ciri umum memiliki warna coklat- ungu tua dengan garisgaris berwarna lebih tua sampai hitam, kayu gubal berwarna putih. Tekstur kayu hampir halus dan arah serat berpadu. Permukaan kayu agak mengkilap.

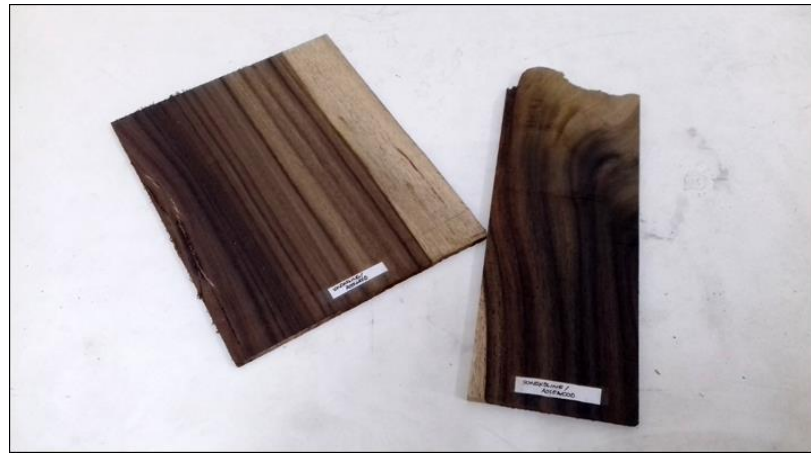

Gambar 2. Limbah Kayu Rose wood / Sonokeling. Sumber : Dokumentasi penulis (2018)

2. Kayu Mahoni atau nama Botaninya Swietenia spp famili Meliaceae. Ciri umum kayu berwarna coklat muda kemerah-merahan atau kekuning-kuningan sampai coklat tua kemerah-merahan, lambat laun menjad tua. Tekstur agak halus. Arah serat berpadu, kadang-kadang bergelombang. Permukaan kayu mengkilap.

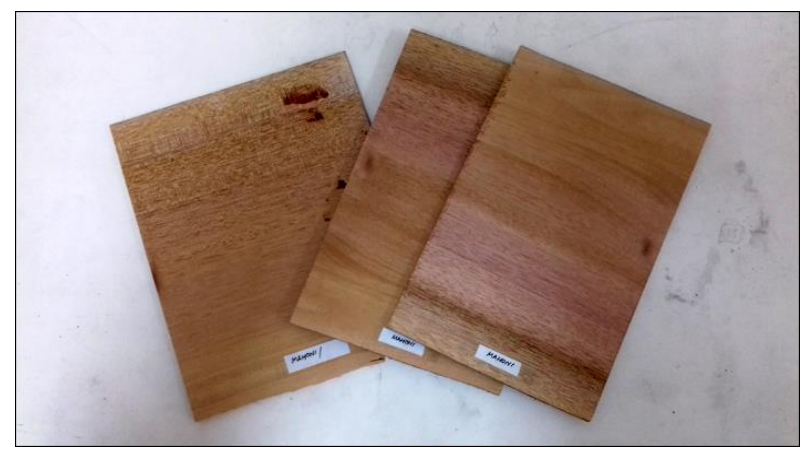

Gambar 3. Limbah Kayu Mahoni Sumber : Dokumentasi penulis (2018)

3. Kayu Trembesi atau nama Botaninya Samanea saman. Warna permukaan kayu bagian teras berwarna gelap sedangkan bagian gubal berwarna putih sangat kontras. Tekstur agak halus dan permukaan kayu agak mengkilap.

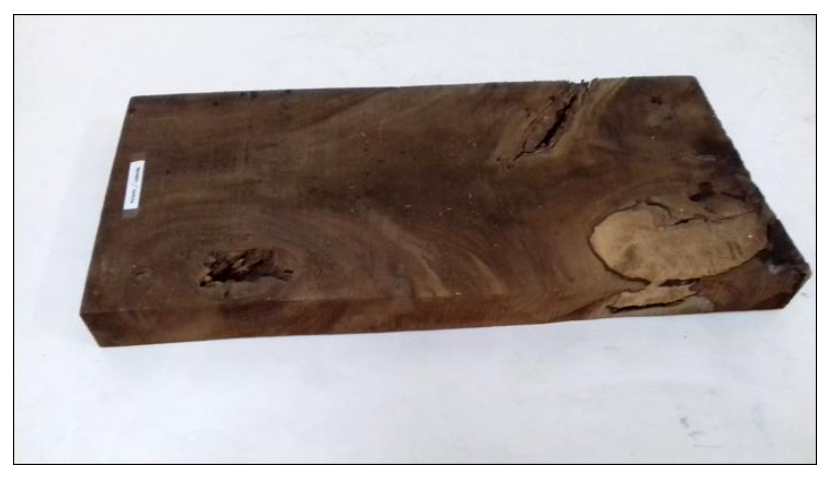

Gambar 4. Limbah Kayu Trembesi Sumber : Dokumentasi penulis (2018)

Berdasarkan data di lapangan, limbah kayu tersebut berupa potongan-potongan dengan ukuran yang berbeda. 
Seperti pada tabel di bawah ini dikelompokan berdasarkan jenis kayu dan ukurannya:

Tabel 1. Jenis dan ukuran limbah kayu

\begin{tabular}{|c|l|c|}
\hline NO & \multicolumn{1}{|c|}{ JENIS KAYU } & UKURAN $(\mathbf{p} \times \mathbf{l} \times \mathbf{t})$ \\
\hline 1 & Kayu Trembesi & $51 \mathrm{~cm} \times 23 \mathrm{~cm} \times 5 \mathrm{~cm}$ \\
\hline 2 & Kayu Mahoni & $20 \mathrm{~cm} \times 15 \mathrm{~cm} \times 0,5 \mathrm{~cm}$ \\
\hline 3 & Kayu Sonokeling & $25 \mathrm{~cm} \times 10 \mathrm{~cm} \times 0,5 \mathrm{~cm}$ \\
\hline 4 & Kayu Trembesi & $25 \mathrm{~cm} \times 18 \mathrm{~cm} \times 0,5 \mathrm{~cm}$ \\
\hline 5 & $\begin{array}{l}\text { Kayu Trembesi dan } \\
\text { Sonokeling }\end{array}$ & $50 \mathrm{~cm} \times 0,5 \mathrm{~cm}$ \\
\hline 6 & Kayu Sonokeling & $62 \mathrm{~cm} \mathrm{\times} 10 \mathrm{~cm} \times 0,2 \mathrm{~cm}$ \\
\hline
\end{tabular}

Dari sampel limbah kayu tersebut dibuat menjadi beberapa alternatif desain produk kriya interior. Dalam prosesnya tetap berpatokan pada tiga hal, yakni produk yang fungsional, karakter tekstur kayu dipertahankan, dan ukuran disesuaikan dengan bahan yang ada.

Desain yang pertama (gambar 5 dan 6) adalah jam meja dan vas bunga berbahan kayu Trembesi dipadu dengan Mahoni pada desain alternatif satu. Sedangkan pada desain alternatif dua berbahan kayu Sonokeling dan Mahoni. Finishing clear doff. Untuk bahan vas dipilih material yang clean yakni acrilyc.

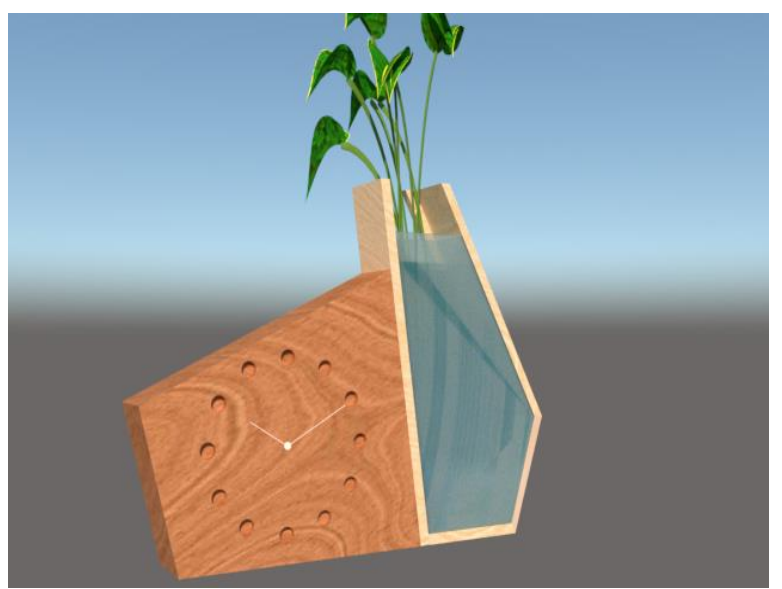

Gambar 5. Desain jam dan vas bunga (alternatif satu) Sumber : Dokumentasi penulis (2018)

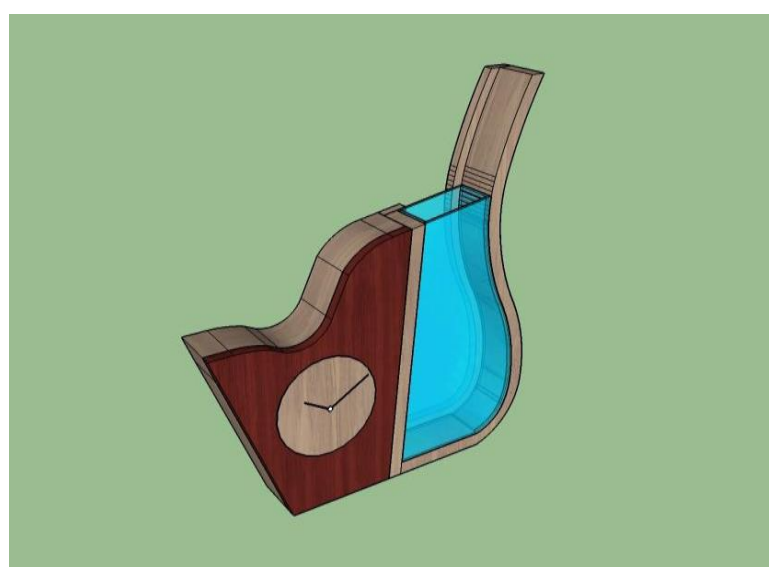

Gambar 6. Desain jam dan vas bunga (alternatif dua) Sumber : Dokumentasi penulis (2018)
Karya desain berikutnya (gambar 7 dan 8) berupa wadah untuk gelas minuman mineral yang dilengkapi dengan kotak kertas tisu serta tempat penyimpanan sendok dan garpu. Satu tempat dengan multifungsi. Berawal dari pengamatan partisipan tentang beberapa peralatan yang terpisah-pisah wadahnya. Dengan pertimbangan efisiensi berusaha untuk disatukan dalam satu tempat.

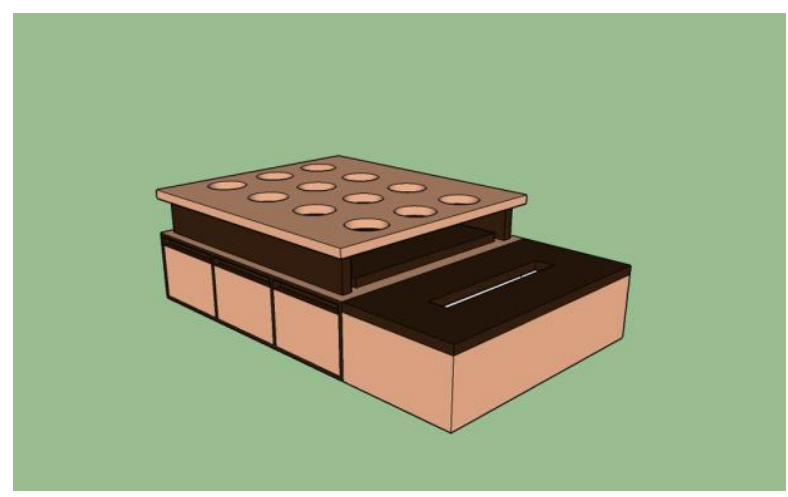

Gambar 7. Desain tempat sajian/wadah (alternatif satu) Sumber : Dokumentasi penulis (2018)

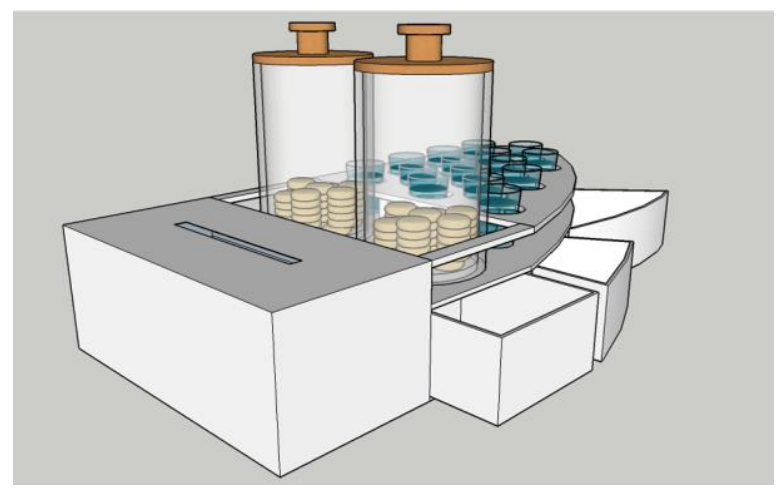

Gambar 8. Desain tempat sajian/wadah (alternatif dua) Sumber : Dokumentasi penulis (2018)

Kedua desain berbahan potongan papan limbah kayu Mahoni dengan tebal kayu 0,5 cm. Kayu Mahoni dipadukan dengan kayu Sonokeling sehingga terlihat kontras warna tekstur kayunya sedangkan untuk finishing clear doff.

Dan desain terakhir (gambar 9 dan 10) berupa lampu meja yang dilengkapi dengan tempat penyimpanan alat tulis. Ide desain berasal dari bagian bawah gagang keris. Kemudian dikembangkan dengan bentuk yang lebih modern dengan menghilangkan dekorasi/ornamentik. Dibentuk lebih simpel dan sederhana namun tetap memperlihatkan tekstur kayu. 


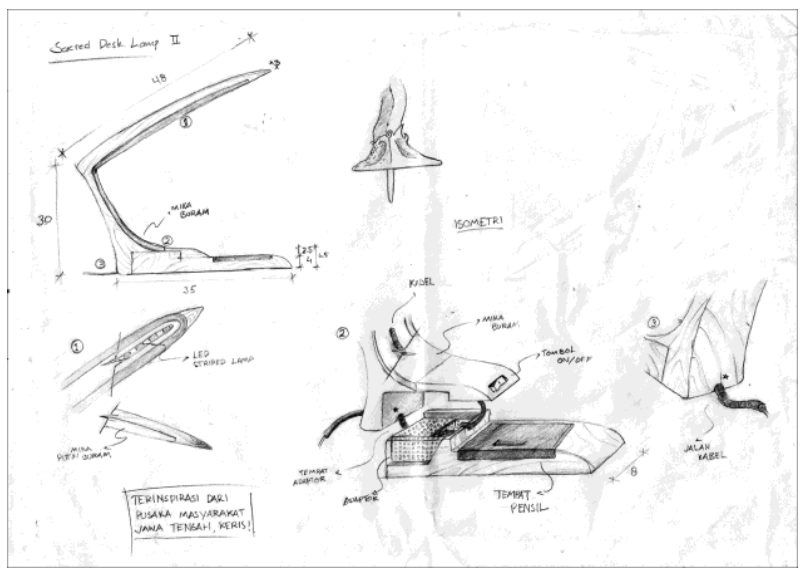

Gambar 9. Desain lampu meja (alternatif satu) Sumber : Dokumentasi penulis (2018)

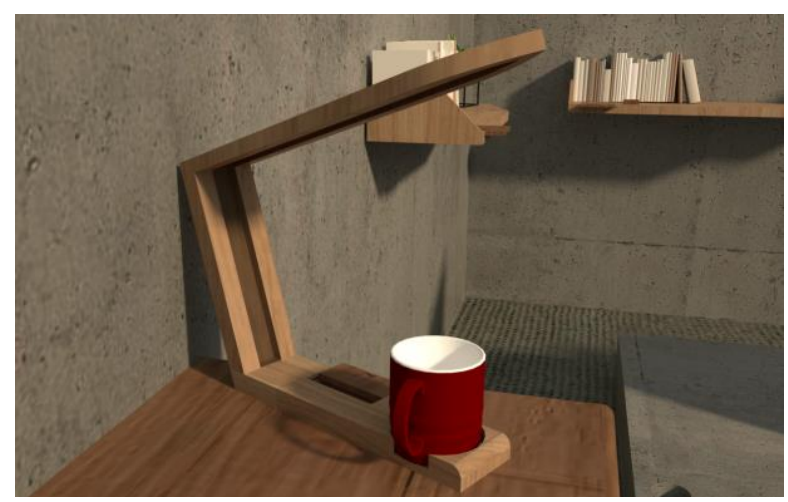

Gambar 10. Desain lampu meja (alternatif dua) Sumber : Dokumentasi penulis (2018)

\section{SIMPULAN}

Material kayu limbah pabrik gitar Genta masih memungkinkan untuk diolah menjadi produk kriya interior lainnya. Material limbah yang awalnya hanya dibuang namun bisa dibuat produk yang fungsional dan tentunya mempunyai nilai ekonomis. Hal ini bisa jadi sebagai solusi untuk mengurangi limbah yang dihasilkan dari industri.

Perkuliahan pada program studi Desain Interior selain sebagai kegiatan belajar mengajar, dapat juga dijadikan kegiatan penelitian yang mengangkat permasalahan nyata ada di masyarakat. Sedangkan solusi pemecahan masalah melalui proses desain.

\section{REFERENSI}

[1] Lawson, Bryan. 2007. Bagaimana Cara Berpikir Desainer (How Designers Think). Yogyakarta : Jalasutra.

[2] Martawijaya, Abdurahim. 2005. Atlas Kayu Indonesia, jilid I. Bogor : Departemen Kehutanan Balai Penelitian dan Pengembangan Kehutanan.

[3] Suptandar, J. Pamudji. 1999. Desain InteriorPengantar Merencana Interior untuk Mahasiswa Disain dan Arsitektur. Jakarta: Djambatan.
[4] Tim Penyusun. 2005. Pedoman Sertifikasi Keahlian Desainer Interior. Jakarta : Himpunan Desainer Interior Indonesia (HDII).

[5] 2008. Buku Sebelas Munas HDII 4-5 November 2008. Jakarta : Himpunan Desain Interior Indonesia (HDII). 